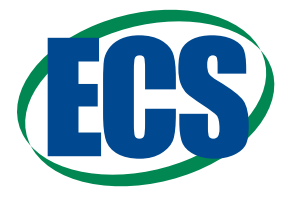

JeS Focus Issue on Semiconductor Electrochemistry and Photoelectrochemistry in Honor of Krishnan Rajeshwar

\title{
Composition-Dependent Optical and Photoelectrochemical Behavior of Antimony Oxide Iodides
}

\author{
Altantuya Ochirkhuyag, ${ }^{1}$ Ildikó Y. Tóth, ${ }^{1}$ Attila Kormányos, ${ }^{2,3}$ Csaba Janáky, ${ }^{2,3, *}$ \\ and Zoltán Kónya ${ }^{10,4, z}$ \\ ${ }^{I}$ Department of Applied and Environmental Chemistry, University of Szeged, H-6720 Szeged, Hungary \\ ${ }^{2}$ Department of Physical Chemistry and Materials Science, University of Szeged, H-6720 Szeged, Hungary \\ ${ }^{3}$ MTA-SZTE "Lendület” Photoelectrochemistry Research Group, University of Szeged, H-6720 Szeged, Hungary \\ ${ }^{4}$ MTA-SZTE Reaction Kinetics and Surface Chemistry Research Group, H-6720 Szeged, Hungary
}

\begin{abstract}
The ongoing search for new photoelectrode materials generated interest toward semiconductors containing multiple anions. In this work, three different antimony oxide iodides $\left(\mathrm{Sb}_{3} \mathrm{O}_{4} \mathrm{I}, \mathrm{Sb}_{8} \mathrm{O}_{11} \mathrm{I}_{2}\right.$, and $\left.\mathrm{Sb}_{5} \mathrm{O}_{7} \mathrm{I}\right)$ were synthesized by anhydrous synthesis. Scanning electron microscopy revealed mainly needle-shaped particles for $\mathrm{Sb}_{3} \mathrm{O}_{4} \mathrm{I}$, elongated plate-shaped ones for $\mathrm{Sb}_{8} \mathrm{O}_{11} \mathrm{I}_{2}$ and wellcrystallized hexagonal particles for $\mathrm{Sb}_{5} \mathrm{O}_{7} \mathrm{I}$. The isoelectric point of the antimony oxide iodides $(\mathrm{pH} \sim 3)$ was independent of the chemical composition. With increasing $\mathrm{pH}$ particles became negatively charged to different extents, depending on the relative amount of oxygen in the samples, through the presence of $\equiv \mathrm{Sb}-\mathrm{O}^{-}$surface functional groups. The optical properties were heavily affected by the composition as well: bandgap energies related to the direct transitions in $\mathrm{Sb}_{3} \mathrm{O}_{4} \mathrm{I}, \mathrm{Sb}_{8} \mathrm{O}_{11} \mathrm{I}_{2}$, and $\mathrm{Sb}_{5} \mathrm{O}_{7} \mathrm{I}$ were 2.16 and 2.74 $\mathrm{eV}, 2.85 \mathrm{eV}$, and $3.25 \mathrm{eV}$, respectively. Photoelectrochemical analysis proved that all samples behave as n-type semiconductors, but the performance in water oxidation showed large variation for the different compositions. The band energy diagram was constructed for all compounds and the composition dependent optoelectronic properties were rationalized on this basis.

(C) The Author(s) 2019. Published by ECS. This is an open access article distributed under the terms of the Creative Commons Attribution Non-Commercial No Derivatives 4.0 License (CC BY-NC-ND, http://creativecommons.org/licenses/by-nc-nd/4.0/), which permits non-commercial reuse, distribution, and reproduction in any medium, provided the original work is not changed in any way and is properly cited. For permission for commercial reuse, please email: oa@electrochem.org. [DOI: 10.1149/2.0311905jes]
\end{abstract}

(cc) BY-NC-ND

Manuscript submitted November 27, 2018; revised manuscript received January 22, 2019. Published February 2, 2019. This paper is part of the JES Focus Issue on Semiconductor Electrochemistry and Photoelectrochemistry in Honor of Krishnan Rajeshwar.

Energy is one of the fundamental pillars of our modern civilization. Nowadays, the most dominant sources for energy production are the non-renewable hydrocarbon fuels. Burning these fuels raised the anthropogenic carbon dioxide emission, increasing the concentration of greenhouse gases. In this way, the overuse of fossil fuels has led to global climate change. Consequently, both economic energy production and its environmental aspects are urgent and serious topics in the field of chemistry. The combination of reducing carbon dioxide concentration in the atmosphere with the application of renewable energy sources, has gained increasing interest. One possible solution is the sunlight-assisted $\mathrm{CO}_{2}$ reduction to different chemical fuels, which can be carried out for example by i) photochemical reduction on photocatalysts or ii) photoelectrochemical (PEC) reduction on semiconducting photoelectrodes. $^{1-7}$ All these processes shall be accompanied by solar driven water oxidation, as the other (anodic) half reaction. The essential component of these processes is a semiconductor photoelectrode. Over the last decades, a large variety of semiconductors have been synthetized and characterized; for example, simple and complex oxides, ${ }^{8-12}$ oxynitrides, ${ }^{13-15}$ and oxysulfides. ${ }^{13,16}$ The vast majority of research interest, however was focused on the oxide family. ${ }^{17-19}$

One of the most studied semiconductors is titanium dioxide, ${ }^{20}$ which has a large bandgap and is thus active in the UV range. Therefore, this material alone cannot be efficiently used for solar energy conversion. It needs modifications, for example, by using a dopant ${ }^{21}$ or construct heterojunction with another material such as $\mathrm{g}-\mathrm{C}_{3} \mathrm{~N}_{4} \cdot{ }^{22}$ More recently, the group 15 elements (e.g., Bi, Sb, Se, N, P) seem to be favorable candidates as photoactive materials. Among them, bismuthbased materials are promising photocatalysts for the degradation of organic pollutants, ${ }^{23-25} \mathrm{HCHO}$ removal, photocatalytic $\mathrm{O}_{2}$ and $\mathrm{H}_{2}$ evolution, and $\mathrm{CO}_{2}$ conversion. ${ }^{26}$ Antimony is another semimetal of the nitrogen group that forms rather rare minerals including stibnite $\left(\mathrm{Sb}_{2} \mathrm{~S}_{3}\right)$, valentinite $\left(\mathrm{Sb}_{2} \mathrm{O}_{3}\right)$, and kermesite $\left(\mathrm{Sb}_{2} \mathrm{~S}_{2} \mathrm{O}\right)$. These are usually present at trace levels in minerals such as ilmenite, $\mathrm{Mg}$ olivine, galena, sphalerite, and pyrite in the Earth's crust. ${ }^{27}$
Antimony oxide based materials - such as antimony organic halide complexes ${ }^{28}$ - open new possibilities in hybrid solar cells and photocatalysts. There are a few studies on these materials, such as on the synthesis of antimony oxide halides ( $\mathrm{SbOCI}, \mathrm{Sb}_{8} \mathrm{O}_{11} \mathrm{CI}_{2}$ ), ${ }^{29}$ on the hydrothermal synthesis of antimony oxyfluorides, ${ }^{30}$ the photosensitive ferroelasticity of $\alpha-\mathrm{Sb}_{5} \mathrm{O}_{7} \mathrm{I}$ crystals, ${ }^{31}$ and the photocatalytic performance of $\mathrm{Sb}_{4} \mathrm{O}_{5} \mathrm{CI}_{2}$ hollow microspheres. ${ }^{32}$ At the same time, a coherent study on the role of chemical composition on the PEC properties is still missing. The bandgap of bismuth oxide halogenides decreases in the periodic table from top to bottom: bismuth oxyfluoride $>$ bismuth oxychloride $>$ bismuth oxybromide $>$ bismuth oxyiodide: $3.5-3.6 \mathrm{eV}$ $>2.9-3.4 \mathrm{eV}>2.3-2.9 \mathrm{eV}>1.8-2.1 \mathrm{eV}$, respectively. ${ }^{33}$ Antimony sulfoiodide showed good visible light photocatalytic activity, ${ }^{34}$ and the sonochemical growth antimony selenoiodide in multiwalled carbon nanotube had promising optical properties and narrow bandgap, as well. ${ }^{35}$

According to the literature, the antimony/bismuth oxide iodide materials have sufficiently narrow bandgap compared to other oxyhalides. ${ }^{23,33,36}$ Yet, there are certain difficulties regarding their synthesis, namely the poor solubility of antimony oxide and the instability of iodine. Therefore, common solvents such as water or alcohols cannot be used, and even hydrochloric acid is unsuitable, because of the competition between iodine and chlorine during the compound formation. Consequently, studies about the synthesis and the photocatalytic/photoelectrochemical characterization of $\mathrm{Sb}_{\mathrm{x}} \mathrm{O}_{\mathrm{y}} \mathrm{I}_{\mathrm{z}}$ compounds are insufficiently detailed in the literature.

In this study, three different antimony oxide iodides were synthesized under anhydrous conditions. ${ }^{37}$ Oxygen content of the samples was changed simply with the synthesis temperature and the molar ratio of precursors. Our main aim was to reveal the effect of the composition (namely the oxygen content in the crystal structure) on the optical and PEC properties.

\section{Materials and Methods}

Chemicals.-Antimony(III) iodide ( $\left.\mathrm{SbI}_{3}\right)$, antimony(II) oxide $\left(\mathrm{Sb}_{2} \mathrm{O}_{3}\right)$, sodium hydroxide $(\mathrm{NaOH})$, and sulfuric acid $\left(\mathrm{H}_{2} \mathrm{SO}_{4}\right)$ were 
Table I. The molar ratio of precursors and temperature of the synthesis.

\begin{tabular}{lll} 
Compounds & $\begin{array}{l}\text { Molar ratio } \\
\left(\mathrm{m}: \mathrm{n}=\mathrm{Sb}_{2} \mathrm{O}_{3}: \mathrm{SbI}_{3}\right)\end{array}$ & $\begin{array}{l}\text { Synthesis } \\
\text { temperature, }\end{array}$ \\
\hline $\mathrm{Sb}_{3} \mathrm{C} \mathrm{O}_{4} \mathrm{I}$ & $8: 2$ & 320 \\
$\mathrm{Sb}_{8} \mathrm{O}_{11} \mathrm{I}_{2}$ & $11: 2$ & 450 \\
$\mathrm{Sb}_{5} \mathrm{O}_{7} \mathrm{I}$ & $14: 2$ & 570
\end{tabular}

purchased from Sigma Aldrich. Isopropanol $\left(\mathrm{C}_{3} \mathrm{H}_{8} \mathrm{O}\right)$ and sodium sulfate $\left(\mathrm{Na}_{2} \mathrm{SO}_{4}\right)$ were bought from WVR and $\mathrm{Ar}(99.999 \%$ purity) was purchased from Messer. All chemicals used in this study were at least in analytical grade, and used without further purification. Ultrapure water (MilliQ) was used for sample processing.

Synthesis of antimony oxide iodides.-Samples were prepared following a method adapted from the literature, according to the equation below. ${ }^{37}$

$\mathrm{m} \mathrm{Sb}_{2} \mathrm{O}_{3}+\mathrm{n} \mathrm{SbI}_{3}=\mathrm{Sb}_{2 \mathrm{~m}+\mathrm{n}} \mathrm{O}_{3 \mathrm{~m}} \mathrm{I}_{3 \mathrm{n}}$ (where $\mathrm{m}$ and $\mathrm{n}$ are integers).

The compounds (Table I) were sealed individually into borosilicate glass ampoules under $0.1-0.2 \mathrm{mBar}$ vacuum. The ampoules were heated by $5^{\circ} \mathrm{C} / \mathrm{min}$ rate in a transparent furnace until the onset of the reaction was noted and then annealed for 48 hours and cooled down with the same rate.

Characterization of antimony oxide iodides.-Powder X-ray diffraction.-All samples were characterized with a Rigaku Miniflex II powder X-ray diffractometer (XRD) using a $\mathrm{Cu} \mathrm{K} \alpha$ radiation source $(\lambda=0.15418 \mathrm{~nm})$ operating at $30 \mathrm{kV}$ and $15 \mathrm{~mA}$ at room temperature. A scanning rate of 4 degrees $\mathrm{min}^{-1}$ was used in the $2 \theta$ $=10-60^{\circ}$ range.

Scanning electron microscopy.-Morphology and composition of the synthesized materials were studied by scanning electron microscopy (SEM). The samples were mounted on a sample holder with carbon conductive adhesive tape. Energy dispersive X-ray spectroscopy (EDX) and high-resolution secondary electron images were taken by a Hitachi S-4700 Type II instrument (30 kV accelerating voltage). EDX quantitative analysis was repeated three times on different areas of the sample and the average was calculated from the repetitions.

Thermogravimetry.-The thermal behavior of antimony oxide iodide samples was investigated using thermogravimetry (TA Instruments Q500 TGA). The instrument worked under a constant flow of air, and the heating rate was $5^{\circ} \mathrm{C} / \mathrm{min}$ up to $700^{\circ} \mathrm{C}$. The samples, between $20-60 \mathrm{mg}$, were placed into high-purity alpha platinum crucibles.

Diffuse reflectance $U V$-vis spectroscopy-Diffuse reflectance spectra in the ultraviolet-visible region (DRS-UV-vis) were recorded at room temperature in the $200-800 \mathrm{~nm}$ range using an Ocean optic bench model USB4000 in the diffuse reflectance mode using spectralgrade $\mathrm{BaSO}_{4}$ as the reference material.

Raman spectroscopy.-Raman spectra were collected using a SENTERRA Raman microscope (Bruker Optics, Inc.) at $532 \mathrm{~nm}$ with a $1 \mathrm{~s}$ integration (with three repetitions) at a resolution of $4 \mathrm{~cm}^{-1}$ and interferometer resolution of $0.5 \mathrm{~cm}^{-1}$.

Zeta potential measurement.-Electrophoretic mobilities of the antimony oxide iodide particles in water-based dispersions were measured at $25 \pm 0.1^{\circ} \mathrm{C}$ in Nano ZS (Malvern) apparatus with a $4 \mathrm{~mW}$ $\mathrm{He}-\mathrm{Ne}$ laser source $(\lambda=633 \mathrm{~nm})$ operating in backscattering mode at an angle of $173^{\circ}$ using disposable zeta cells (DTS 1060). The Smoluchowski equation was applied to convert electrophoretic mobilities to zeta potential values. The accuracy of the measurements was $\pm 5 \mathrm{mV}$. The effect of $\mathrm{pH}\left(3.1,4.7,6.5\right.$ and 9.6, adjusted by $\mathrm{H}_{2} \mathrm{SO}_{4}$ and $\mathrm{NaOH}$ solutions) was studied at $10 \mathrm{mM} \mathrm{Na} \mathrm{SO}_{4}$ and at $25^{\circ} \mathrm{C}$. The prepared samples were left at rest for two hours, and the zeta potential measurements were started after 1 minute ultrasonication.
Current-Voltage characteristic.-Antimony oxide iodide suspensions were drop-casted on a glass substrate with gold interdigitated electrodes (Micrux technologies, Spain). The drop-casted samples were placed in a temperature-controlled stage (Linkam, HFS600E). The current-voltage (I-V) characteristics were recorded in the sensor stage in argon atmosphere $(20 \mathrm{ml} / \mathrm{min})$ using a Keithley 2401 Source meter in a four-probe configuration.

Kelvin probe measurements coupled with ambient pressure $U V$ photoelectron spectroscopy.- Kelvin probe measurements were performed using the KP Technology APS04 instrument. ${ }^{38}$ As the first step, the Fermi level of the $2 \mathrm{~mm}$ in diameter gold alloy-coated tip was determined by measuring the Fermi level of a silver reference target $\left(E_{\mathrm{Fermi}, \text { Au tip }}=-4.72 \mathrm{eV}\right)$. The oxyhalide samples were dropcasted on an aluminum sample mount from a dispersion $(c=5 \mathrm{mg}$ $\mathrm{cm}^{-3}$ in isopropanol). The tip was vibrated over the sample surface at a fixed height $(\sim 1 \mathrm{~mm})$ and amplitude $(0.2 \mathrm{~mm})$, with a constant frequency $(70 \mathrm{~Hz})$. Contact potential difference $(\mathrm{CPD})$ was measured between the sample and the Kelvin probe tip after electric equilibrium was reached.

Ambient pressure UV photoelectron spectroscopy (APS) measurements were performed with a stationary Kelvin-probe tip. The sample surface was illuminated with a 4-5 mm spot-size, variable energy UV light source $(\lambda=180 \mathrm{~nm}-340 \mathrm{~nm})$. The UV light generates an electron cloud from the semiconductor if the energy of illumination is higher than the valence band energy $\left(E_{\mathrm{VB}}\right)$. Under atmospheric conditions secondary ions form (such as $\mathrm{N}^{2-}, \mathrm{O}^{2-}$ ). These ions are collected by the Kelvin-probe tip, thus a current is measured. In the case of semiconductors, there is a cube-root dependence between this current and the excitation energy. ${ }^{38}$ The $E_{\mathrm{VB}}$ was determined as the intersection of the baseline and the rise in the cube root of the photoemission.

Electrode preparation for PEC measurements. - All samples were dispersed in isopropanol $\left(c=5 \mathrm{mg} \mathrm{cm}^{-3}\right)$ by ultrasonic treatment for $30 \mathrm{~min}$ before spray-coating. The samples were spray-coated on a preheated $\left(140^{\circ} \mathrm{C}\right)$ glassy carbon electrode surface, using an Alder AD320 type airbrush and a homemade spray-coater robot, operated with 1 bar compressed air. The loading of the materials on the electrode surface was around $120 \mu \mathrm{g} \mathrm{cm}^{-2}$. After the spray-coating step, the resulted thin layers were heat treated in an oven at $200^{\circ} \mathrm{C}$ for $120 \mathrm{~min}$. This annealing had a dual purpose: to remove any residual traces of the solvent, and to enhance the adhesion of the spray-coated layers to the underlying electrode surface.

PEC measurements. - All PEC measurements were performed using a Metrohm Autolab PGSTAT302 type potentiostat/galvanostat in a sealed, custom designed one-compartment, three electrodes quartz cell. Glassy carbon electrodes, modified with the various antimony oxide iodide samples were used as working electrode, while a Pt sheet and $\mathrm{Ag} / \mathrm{AgCl} / 3 \mathrm{M} \mathrm{NaCl}$ were employed as counter, and reference electrodes, respectively. The irradiation source was a $300 \mathrm{~W} \mathrm{Hg}-\mathrm{Xe}$ arc discharge lamp (Hamamatsu L10852). The radiation source was placed $5 \mathrm{~cm}$ away from the illuminated working electrode surface and shone through the quartz window of the cell. The output power, reaching the working electrode surface was $180 \mathrm{~mW} \mathrm{~cm}^{-2}$. The frequency of the chopped illumination was $0.1 \mathrm{~Hz}$, while the applied sweep rate was $2 \mathrm{mV} \mathrm{s}^{-1}$. $0.1 \mathrm{M} \mathrm{Na}_{2} \mathrm{SO}_{4}$ was used as an electrolyte solution, saturated by Ar for 30 minutes before each measurement. The gas flow was continuous over the saturated electrolyte during the measurements. Incident photon-to-charge conversion efficiency (IPCE) measurements were performed on a Newport Quantum Efficiency Measurement System (QEPVSI-B) in a single compartment, three-electrode quartz electrochemical cell. The wavelength range was $280-500 \mathrm{~nm}(\Delta \lambda=10 \mathrm{~nm}$ resolution). Measurements were performed in $0.1 \mathrm{M} \mathrm{Na}_{2} \mathrm{SO}_{4}$ solution saturated with Ar. Electrodes were held at $1.1 \mathrm{~V}$ constant potential during the measurements.

\section{Results and Discussion}

Physical and chemical characterization.-Three different antimony oxide iodides formed at 320,450 , and $570^{\circ} \mathrm{C}$. Due to increasing oxygen content with the increasing temperature, the color first changed 


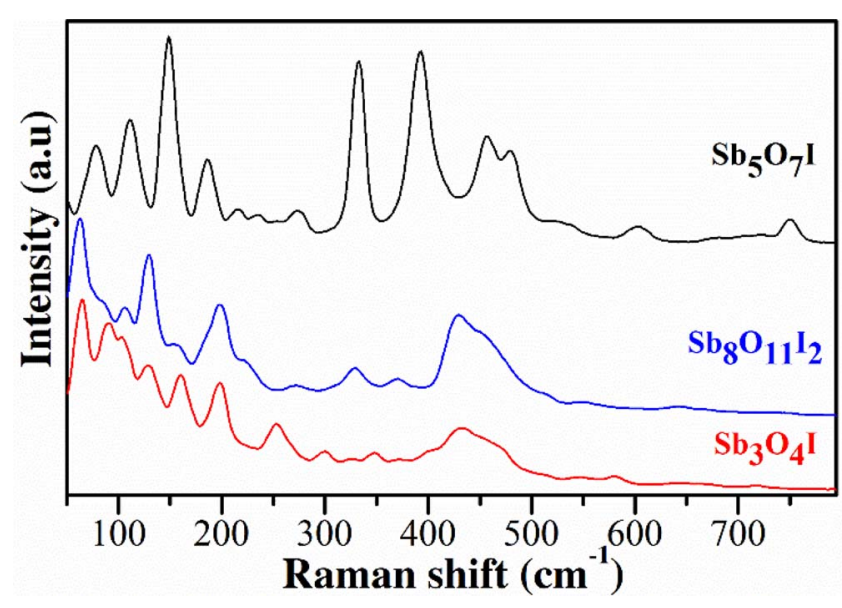

Figure 1. Raman spectra of the samples: $\mathrm{Sb}_{3} \mathrm{O}_{4} \mathrm{I}$ : red, $\mathrm{Sb}_{8} \mathrm{O}_{11} \mathrm{I}_{2}$ : blue, $\mathrm{Sb}_{5} \mathrm{O}_{7} \mathrm{I}$ : black.

from yellowish to greenish and finally to white in the series of samples (Fig. S1). All antimony oxide iodides have similar Raman bands, which also match literature data (Fig. 1 and Table S1). ${ }^{39}$ Raman shifts of $\mathrm{Sb}_{2} \mathrm{O}_{3}$ (precursor 1) corresponds to the orthorhombic structure, ${ }^{40}$ while $\mathrm{SbI}_{3}$ (precursor 2) has trigonal one (Fig. S2). The Raman shift of $\mathrm{Sb}_{3} \mathrm{O}_{4} \mathrm{I}$ at $65 \mathrm{~cm}^{-1}$ agrees with the antimony iodine vibration, while the shifts at 103 and $298 \mathrm{~cm}^{-1}$ belong to the orthorhombic antimony oxide structure. ${ }^{41}$ In the case of $\mathrm{Sb}_{8} \mathrm{O}_{11} \mathrm{I}_{2}$, there were similar bands to $\mathrm{Sb}_{3} \mathrm{O}_{4} \mathrm{I}$, although their intensity increased due to the crystallization at a higher temperature. Additionally, new shifts emerged at 218,270 , and $329 \mathrm{~cm}^{-1}$ corresponding to the monoclinic structure of oxide iodide. For $\mathrm{Sb}_{5} \mathrm{O}_{7} \mathrm{I}$, the shift at $148 \mathrm{~cm}^{-1}$ belongs to the antimony iodine vibration. New shifts also occurred at 456, 482, 601, and $750 \mathrm{~cm}^{-1}$ because of the enhanced crystallinity and the increased oxygen content in the structure.

The structure and phase purity of the antimony oxide iodide samples were studied by XRD. The diffraction patterns of $\mathrm{Sb}_{3} \mathrm{O}_{4} \mathrm{I}$ are in- dexed to the structure of orthorhombic $\mathrm{Sb}_{3} \mathrm{O}_{4} \mathrm{I}$ and monoclinic phase (Fig. 2a). ${ }^{42}$ The diffraction of $\mathrm{Sb}_{8} \mathrm{O}_{11} \mathrm{I}_{2}$ matched with the reference monoclinic phase pure $\mathrm{Sb}_{8} \mathrm{O}_{11} \mathrm{I}_{2}$ (Fig. 2b). Due to the similar ratio of oxide and iodine content of $\mathrm{Sb}_{3} \mathrm{O}_{4} \mathrm{I}$ and $\left(\mathrm{Sb}_{4} \mathrm{O}_{5} \mathrm{I}\right) \times 2$ (empirical formula: $\mathrm{Sb}_{8} \mathrm{O}_{11} \mathrm{I}_{2}$ ), the unit cell of the crystal structure is similar and therefore XRD patterns were analogous, too. Diffraction peaks of $\mathrm{Sb}_{5} \mathrm{O}_{7} \mathrm{I}$ matched with the structure of the well-crystallized hexagonal $\mathrm{Sb}_{5} \mathrm{O}_{7} \mathrm{I}$ (Fig. 2c). ${ }^{43,31}$ EDX results confirmed the chemical purity of the antimony oxide iodides (Fig. S3a), since there were only antimony, iodine, and oxygen in the samples. Based on quantitative analysis (Fig. S3b), the chemical composition of the samples was $\mathrm{Sb}_{2.89} \mathrm{O}_{4} \mathrm{I}$, then $\mathrm{Sb}_{3.45} \mathrm{O}_{5.5} \mathrm{I}$ (x 2), and finally $\mathrm{Sb}_{4.55} \mathrm{O}_{7} \mathrm{I}$, which are very similar to the theoretical values $\left(\mathrm{Sb}_{3} \mathrm{O}_{4} \mathrm{I}, \mathrm{Sb}_{8} \mathrm{O}_{11} \mathrm{I}_{2}\right.$, and $\mathrm{Sb}_{5} \mathrm{O}_{7} \mathrm{I}$, respectively).

The thermal stability of the compounds was assessed with thermogravimetric analysis (Fig. S4). The decomposition reactions follow the mechanisms listed in Table II. $\mathrm{Sb}_{3} \mathrm{O}_{4} \mathrm{I}$ decomposes in three steps. The first weight change (about $4 \%$ ) at $150^{\circ} \mathrm{C}$ indicates the sublimation of $\mathrm{I}_{2}$. Then, the second weight loss (about $7 \%$ ) that occurs at $480^{\circ} \mathrm{C}$ demonstrates the sublimation of $\mathrm{SbI}_{3} .{ }^{37}$ The third, and largest weight change (75\%) represents the sublimation of $\mathrm{Sb}_{2} \mathrm{O}_{3}$. The material left (14\% of the initial weight) corresponds to antimony (IV) oxide and the supposed mechanism for the whole process is described as Equation 1. The phase-pure $\mathrm{Sb}_{8} \mathrm{O}_{11} \mathrm{I}_{2}$ decomposed in two steps (4\% and $81 \%$ weight changes) and at the end, the residual weights around $15 \%$ (Equation 2). The $\mathrm{Sb}_{5} \mathrm{O}_{7} \mathrm{I}$ decomposed in one step (91\%) that is described with Equation 3. ${ }^{44}$ Overall, the main weight losses shifted to slightly higher temperatures with the increasing oxygen content of the samples.

The SEM image in Fig. 3a displays the powder sample of $\mathrm{Sb}_{3} \mathrm{O}_{4} \mathrm{I}$ that consists of micrometer-sized needle-shaped particles. ${ }^{42}$ The increased synthesis temperature $\left(450^{\circ} \mathrm{C}\right)$ and the $\mathrm{m}: \mathrm{n}=11: 2$ molar ratio led to the morphological transformation from needle-shaped to small plate-shaped monoclinic particles of $\mathrm{Sb}_{8} \mathrm{O}_{11} \mathrm{I}_{2}$ (Fig. 3b). Finally, the $\mathrm{Sb}_{5} \mathrm{O}_{7} \mathrm{I}$ sample presents larger particles with the hexagonal crystal structure (Fig. 3c). ${ }^{43}$

Surface protonation/deprotonation events are important for electrode materials to be studied in proton-coupled electron transfer reactions. The zeta potential of the antimony oxide iodide particles declines with increasing $\mathrm{pH}$ (Fig. 4). Furthermore, the increasing
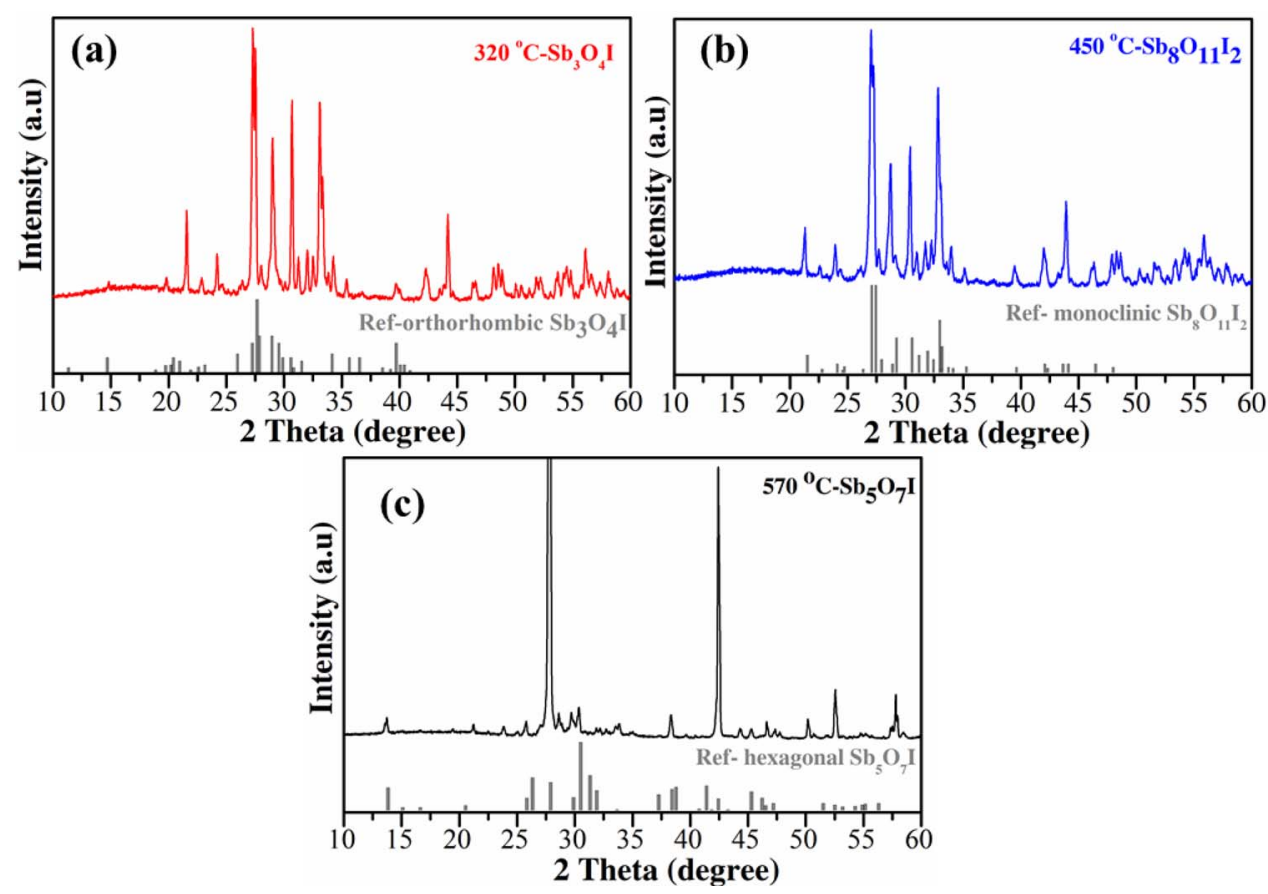

Figure 2. XRD patterns of antimony oxide iodide references and samples synthesized at $320^{\circ} \mathrm{C}(\mathrm{a}), 450^{\circ} \mathrm{C}(\mathrm{b})$ and $570^{\circ} \mathrm{C}(\mathrm{c})$ with ratio of $\mathrm{m}\left(\mathrm{Sb}_{2} \mathrm{O}_{3}\right): \mathrm{n}\left(\mathrm{SbI}_{3}\right)=$ $8: 2,11: 2$ and $14: 2$, respectively. 
Table II. The proposed mechanism of the thermal decomposition of the synthesized antimony oxide iodide samples based on the TGA.

Supposing mechanism of the thermal decomposition
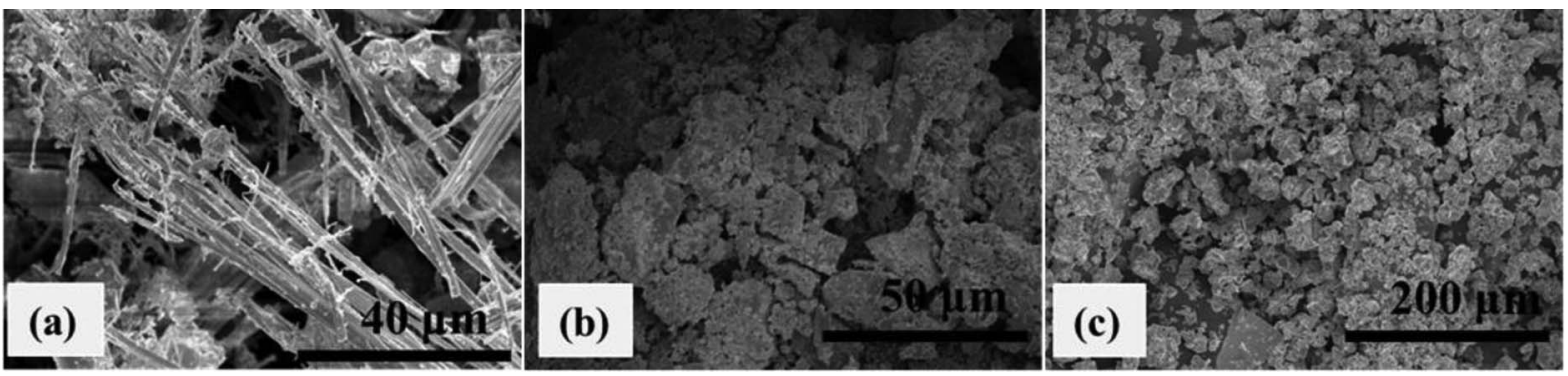

Figure 3. SEM images of the as-synthesized antimony oxide iodide powder sample a) $\mathrm{Sb}_{3} \mathrm{O}_{4} \mathrm{I}, \mathrm{c}$ ) $\mathrm{Sb}_{8} \mathrm{O}_{11} \mathrm{I}_{2}$ and c) $\mathrm{Sb}_{5} \mathrm{O}_{7} \mathrm{I}$.

relative amounts of oxygen in the antimony oxide iodide particles shift the zeta potential gradually to the more negative range, which shows the larger amount of negative charges on the surface. In aqueous media, surface hydroxyl groups can form on the dispersed particles, in this case $\mathrm{Sb}-\mathrm{OH}$ groups. Depending on the $\mathrm{pH}$ of the dispersions, these surface functional groups can be protonated $\left(\mathrm{Sb}-\mathrm{OH}_{2}{ }^{+}\right)$or deprotonated $\left(\mathrm{Sb}-\mathrm{O}^{-}\right)$, therefore the surface of the particles becomes charged. The negative charge on the surface of the antimony oxide iodide particles is caused by the presence of the $\equiv \mathrm{Sb}-\mathrm{O}^{-}$groups, and its amount is increasing with the $\mathrm{pH}$ and the relative amount of the oxygen in the bulk materials, too. The isoelectric point (IEP) was at $\mathrm{pH} \sim 3$ independently from the relative amount of oxygen in the samples. This piece of data agrees well with the IEP values of different antimony oxides (IEP $=2.9$ for senarmontite $\left(\mathrm{Sb}_{2} \mathrm{O}_{3}\right)$ and IEP $=3.2$ for valentinite $\left.\left(\mathrm{Sb}_{2} \mathrm{O}_{3}\right)\right){ }^{45}$ Finally, the increasing amount of the $\equiv \mathrm{Sb}-\mathrm{O}^{-}$groups as a function of $\mathrm{pH}$ and chemical composition results in a higher colloidal stability of the water-based dispersions (see the inserted images in Fig. 4).

The above-discussed phenomena can influence the activity of these materials in proton-coupled electron transfer reactions. Among them, hydrogen evolution $\left(2 \mathrm{H}^{+}+2 \mathrm{e}^{-}=\mathrm{H}_{2}\right)$, carbon dioxide reduction $\left(\mathrm{CO}_{2}+2 \mathrm{e}^{-}+2 \mathrm{H}^{+}=\mathrm{CO}+\mathrm{H}_{2} \mathrm{O}\right)$, and water oxidation $\left(2 \mathrm{H}_{2} \mathrm{O} \rightarrow\right.$ $\mathrm{O}_{2}+4 \mathrm{e}^{-}+4 \mathrm{H}^{+}$) are of particular relevance for solar fuel generation. These reactions need the presence of either a proton donor or acceptor

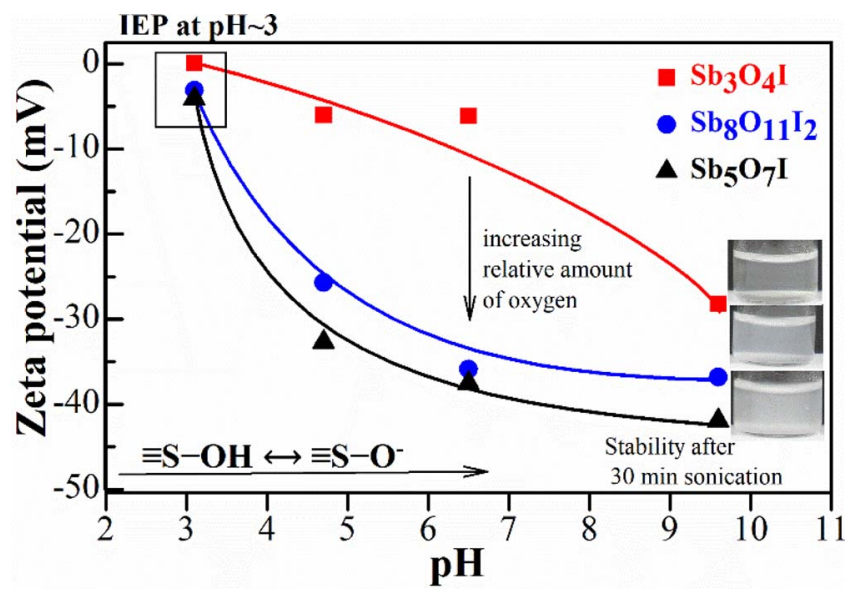

Figure 4. The zeta potential measurement result of antimony oxide iodides (at $10 \mathrm{mM} \mathrm{Na}_{2} \mathrm{SO}_{4}$ and at $25^{\circ} \mathrm{C}$ ). The inserted photos represent the increasing colloidal stability of the antimony oxide iodides particles depending on their relative amount of oxygen. component. There are many opportunities to ensure the proton donor component, for instance, with the surface metal-hydrogen $(\mathrm{M}-\mathrm{H})$ groups or the carboxyl/carboxylate groups of the cobalt porphyrin complex $\left(\mathrm{CoP}-\mathrm{COOH} / \mathrm{CoP}-\mathrm{COO}^{-}\right) .{ }^{46-48}$ Based on the results of the zeta potential measurements, the antimony oxide iodide particles can behave as proton donors at higher $\mathrm{pH}$ values $\left(\equiv \mathrm{Sb}-\mathrm{OH} \rightarrow \equiv \mathrm{Sb}-\mathrm{O}^{-}\right.$ $+\mathrm{H}^{+}$), and proton acceptors at lower $\mathrm{pH}$. Thus the PEC behavior of the $\mathrm{Sb}_{\mathrm{x}} \mathrm{O}_{\mathrm{y}} \mathrm{I}_{\mathrm{z}}$ likely depends on the amount of $\mathrm{Sb}-\mathrm{O}^{-} / \mathrm{Sb}-\mathrm{OH}_{2}{ }^{+}$ surface groups, and so on their oxygen content.

Optical and photoelectrochemical properties.-Diffuse reflectance UV-Vis spectroscopy was employed to estimate the bandgap values of antimony oxide iodides (Fig. 5a). The edge of adsorption has shifted toward the shorter wavelengths by the increasing synthesis temperature. Bandgaps of the materials were determined by using the Tauc analysis. ${ }^{49,50}$ The direct bandgap of $\mathrm{Sb}_{3} \mathrm{O}_{4} \mathrm{I}, \mathrm{Sb}_{8} \mathrm{O}_{11} \mathrm{I}_{2}$ and $\mathrm{Sb}_{5} \mathrm{O}_{7} \mathrm{I}$ are estimated to be $2.16 \mathrm{eV}$ and $2.74 \mathrm{eV}, 2.85 \mathrm{eV}$ and 3.25 $\mathrm{eV}$, respectively (Fig. 5b). The I-V polarization curves of antimony oxide iodides (Fig. 6) show the relationship between the current flowing through the compound and the applied voltage. The I-V curve of $\mathrm{Sb}_{3} \mathrm{O}_{4} \mathrm{I}$ is almost linear, indicating a higher conductivity. The resistivity of both the $\mathrm{Sb}_{8} \mathrm{O}_{11} \mathrm{I}_{2}$ and $\mathrm{Sb}_{5} \mathrm{O}_{7} \mathrm{I}$ samples is larger, and they both showed nonlinear I-V characteristics, typical for semiconductors.

Optoelectronic properties of the antimony oxyhalides were further studied by Kelvin probe and APS measurements. ${ }^{38} E_{\mathrm{VB}}$ of the three systems were calculated from APS measurements (Fig. S5a-c). The $E_{\mathrm{VB}}$ values $\left(-5.80 \mathrm{eV}\right.$ for $\mathrm{Sb}_{3} \mathrm{O}_{4} \mathrm{I},-5.63 \mathrm{eV}$ for $\mathrm{Sb}_{8} \mathrm{O}_{11} \mathrm{I}_{2}$, and -5.11 $\mathrm{eV}$ for $\left.\mathrm{Sb}_{5} \mathrm{O}_{7} \mathrm{I}\right)$ systematically shifted toward more positive energies with the increasing oxygen content in the crystal structure. The density of states plots were also recorded (except for the $\mathrm{Sb}_{5} \mathrm{O}_{7} \mathrm{I}$ sample due to the noise, arising from the small photoemission signal). To determine Fermi levels, CPD measurements were performed (Fig. S6). $E_{\mathrm{F}}$ values are closer to $E_{\mathrm{CB}}\left(-4.47 \mathrm{eV}\right.$ for $\mathrm{Sb}_{3} \mathrm{O}_{4} \mathrm{I}$ and $-3.89 \mathrm{eV}$ for $\left.\mathrm{Sb}_{8} \mathrm{O}_{11} \mathrm{I}_{2}\right)$, which suggests n-type semiconducting behavior. Contrastingly, $E_{\mathrm{P}}$ of the $\mathrm{Sb}_{5} \mathrm{O}_{7} \mathrm{I}$ sample is located right in the middle of the bandgap. Similarly, to the $E_{\mathrm{VB}}$ energies, $E_{\mathrm{F}}$ values also shifted to more positive energies by the increasing oxygen content. Finally, band diagrams were constructed (Fig. 7) from the $E_{\mathrm{VB}}, E_{\mathrm{F}}$ values and the bandgaps, to visualize the effect of the composition on the energetics.

The PEC behavior of the spray-coated samples was investigated by linear sweep photovoltammetry. Bandgap data, determined from the Tauc plots (Fig. 5b) suggest that both $\mathrm{Sb}_{3} \mathrm{O}_{4} \mathrm{I}$ and $\mathrm{Sb}_{8} \mathrm{O}_{11} \mathrm{I}_{2}$ can be excited by visible light. Therefore, the first experiments were carried out using a solar simulator as a light source (Fig. S7). Only marginal photocurrents were seen in the case of the $\mathrm{Sb}_{5} \mathrm{O}_{7} \mathrm{I}$ sample $\left(E_{\mathrm{BG}}=3.25 \mathrm{eV}\right)$. For the other two materials, however, the photocurrents were slightly higher. Much better results were achieved using a 

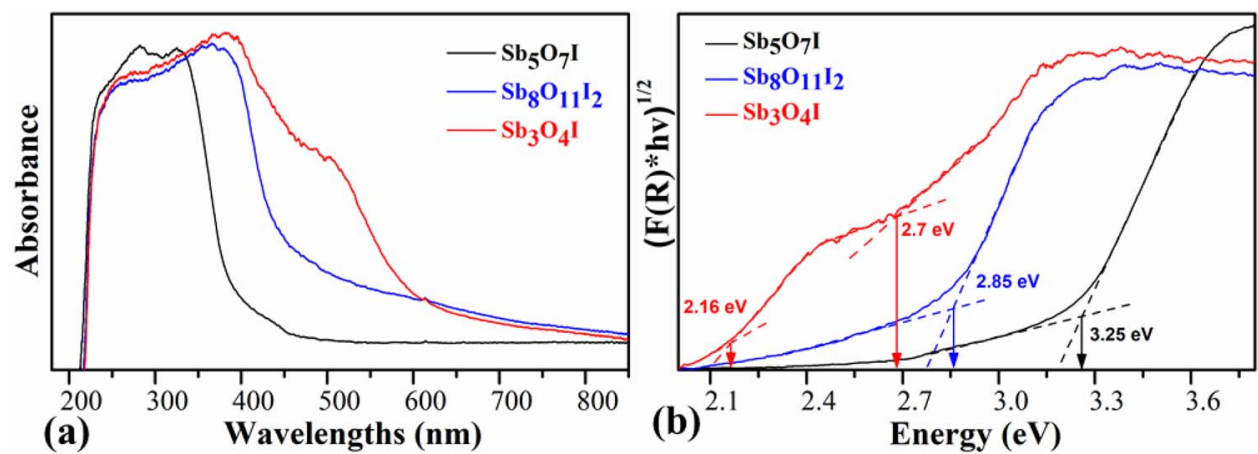

Figure 5. Diffuse reflectance UV-Vis spectra of the synthesized antimony oxide iodides (a) and Tauc plots, constructed from the spectra presented in Figure 5a (b).

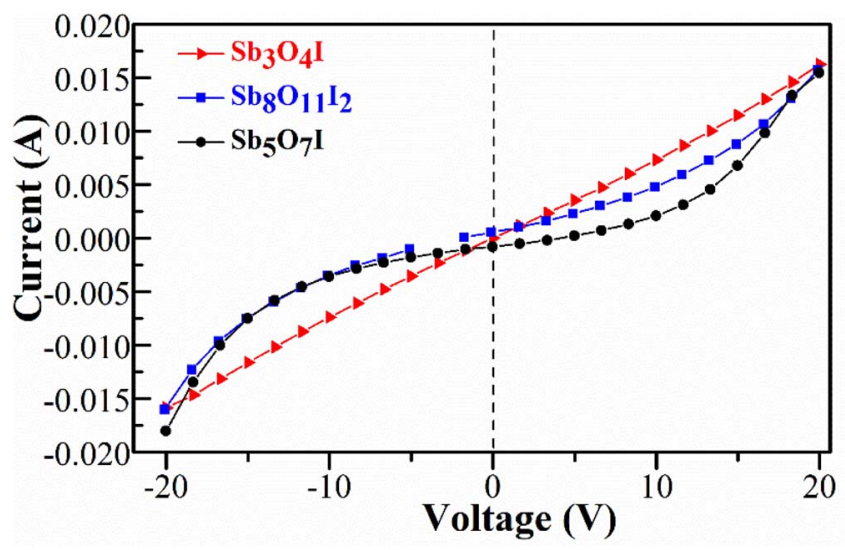

Figure 6. The characteristic I-V curves of the antimony oxyhalides recorded at $25^{\circ} \mathrm{C}$ in argon atmosphere.

$\mathrm{Hg}-\mathrm{Xe}$ arc lamp as the light source (Fig. 8a). Anodic photocurrents were recorded suggesting an n-type behavior, which is in line with the PEC data of other oxyhalides in the literature. ${ }^{32,51,52}$ The major difference from other oxyhalides reported in the literature is in the magnitude of photocurrents. Considerably higher photocurrents were harvested in this study than in those studies reported in the literature (several hundred $\mu \mathrm{A}$ vs. $\mu \mathrm{A}$ ). ${ }^{32,51,52}$ Maximum values were recorded at $+1.0 \mathrm{~V}$, at which it reached its stationary value. Importantly, the dark current remained negligible even at this potential. The shape of the photovoltammograms is similar for all three materials. The photocurrent values, however, gradually increased in the series of samples, reaching the highest value $\left(250 \mu \mathrm{A} \mathrm{cm}^{-2}\right)$ in the case of the $\mathrm{Sb}_{5} \mathrm{O}_{7} \mathrm{I}$. Importantly, these photocurrents were obtained without any sacrificial electron donor (hole-scavenger), therefore it describes the water oxidation activity. Fig. 8b shows the photoaction spectra, recorded for the various antimony oxide iodides. The characteristics of the three curves are similar, showing relatively low quantum efficiency values (up to $2 \%$ in the UV-range). Bandgap values were estimated by fitting a linear to the cutoff region of each curve and extrapolating to the wavelength axis. Bandgap energies of $3.31 \mathrm{eV}\left(\mathrm{Sb}_{5} \mathrm{O}_{7} \mathrm{I}\right)$, $2.95 \mathrm{eV}\left(\mathrm{Sb}_{8} \mathrm{O}_{11} \mathrm{I}_{2}\right)$ and $2.65 \mathrm{eV}\left(\mathrm{Sb}_{3} \mathrm{O}_{4} \mathrm{I}\right)$ were calculated, which all fall close to the ones, obtained from the diffuse reflectance UV-Vis spectra.

\section{Conclusions}

This work presented an anhydrous synthesis method for three different antimony oxide iodides $\left(\mathrm{Sb}_{3} \mathrm{O}_{4} \mathrm{I}, \mathrm{Sb}_{8} \mathrm{O}_{11} \mathrm{I}_{2}\right.$, and $\left.\mathrm{Sb}_{5} \mathrm{O}_{7} \mathrm{I}\right)$ and studied their PEC properties in a systematic manner for the first time. The employed synthesis allowed to control the composition of the samples, tailoring the iodide/oxygen ratio in the structure. This relative oxygen content dictated the surface charge of the particles, due to the presence of $\mathrm{Sb}-\mathrm{O}^{-}$surface functional groups. The bandgap energy of the materials varied in the range of 2.16 and $3.25 \mathrm{eV}$, also depending on the oxygen content. PEC measurements illustrated all samples are n-type semiconductors with notable photocurrent values in the water oxidation reaction. Overall, we have shown that these mixed antimony oxide iodides are possible candidates to be employed (a)

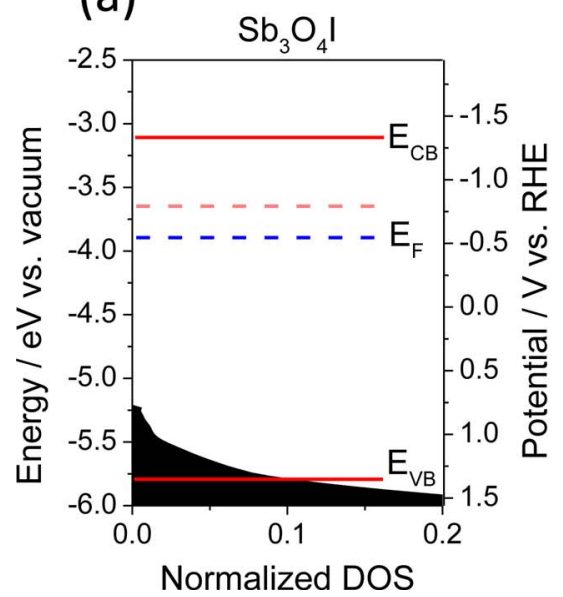

(b)

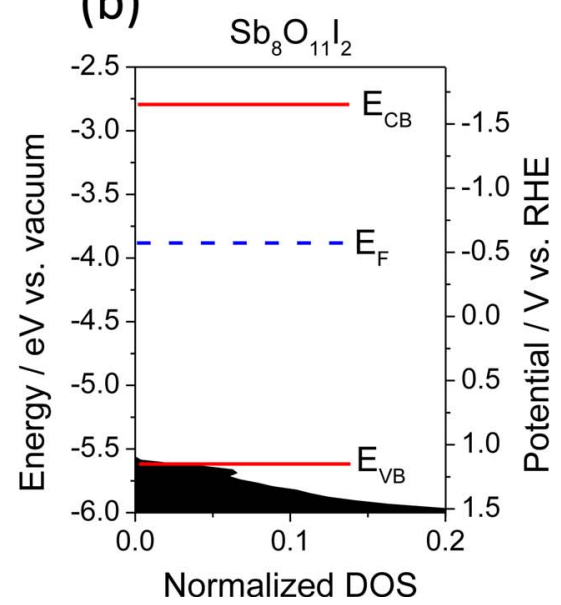

(c)

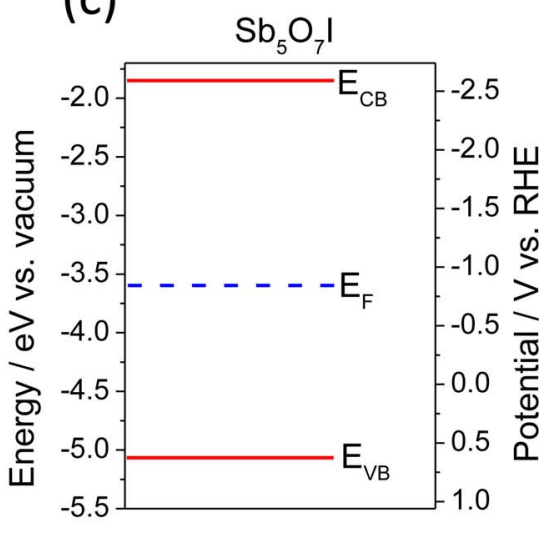

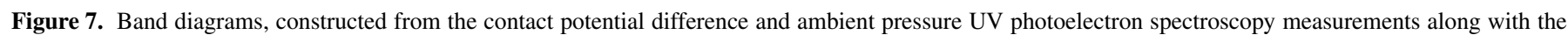
density of states plots for $\mathrm{Sb}_{3} \mathrm{O}_{4} \mathrm{I}$ (the sub-bandgap is marked with light pink) (a), $\mathrm{Sb}_{8} \mathrm{O}_{11} \mathrm{I}_{2}$ (b) and for $\mathrm{Sb}_{5} \mathrm{O}_{7} \mathrm{I}$ (c). 


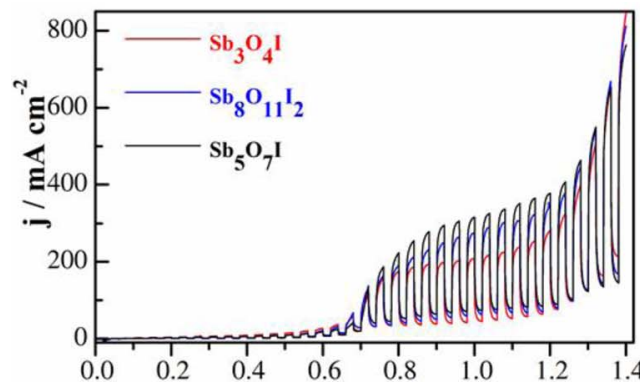

(a)

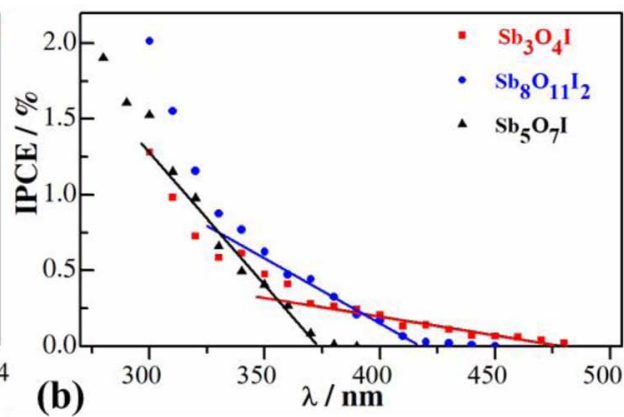

(b)

Figure 8. (a) Linear sweep photovoltammograms recorded for the various antimony oxide iodide samples. A Hg-Xe lamp was used as a light source with a chopping frequency of $0.1 \mathrm{~Hz}$. Measurements were performed in $0.1 \mathrm{M} \mathrm{Na}_{2} \mathrm{SO}_{4}$ solution applying $2 \mathrm{mV} \mathrm{s}^{-1}$ sweep rate. (b) IPCE curves, recorded for the various antimony oxide iodide samples in $0.1 \mathrm{M} \mathrm{Na}_{2} \mathrm{SO}_{4}$ solution applying $\mathrm{E}=1.1 \mathrm{~V}$ potential.

in solar energy conversion, and their optoelectronic properties can be tailored by controlling the composition.

\section{Acknowledgments}

This work was financially supported by the GINOP 2.3.2/201513 project. The authors are thankful to Dr. Bíborka Janáky-Bohner (University of Szeged, Hungary) for her support during the manuscript preparation.

\section{ORCID}

Csaba Janáky (1D https://orcid.org/0000-0001-5965-5173

Zoltán Kónya (1D https://orcid.org/0000-0002-9406-8596

\section{References}

1. E. Kalamaras, M. M. Maroto-Valer, M. Shao, J. Xuan, and H. Wang, Catal. Today, 317, 56 (2018).

2. L. Wang, J. Zhao, H. Liu, and J. Huang, J. Taiwan Inst. Chem. Eng., 93, 590 (2018).

3. A. F. Lee, J. A. Bennett, J. C. Manayil, and K. Wilson, Chem. Soc. Rev., 43, 7887 (2014)

4. J. Ran, J. Zhang, J. Yu, M. Jaroniec, and S. Z. Qiao, Chem. Soc. Rev., 43, 7787 (2014).

5. M. N. Kaydouh, N. El Hassan, A. Davidson, S. Casale, H. El Zakhem, and P. Massiani, Comptes Rendus Chim., 18, 293 (2015).

6. O. D. Ozinger and N. O. Deutschmann, in Ullmann's Encyclopedia of Industrial Chemistry, (2009).

7. S. Pavasupree, S. Ngamsinlapasathian, M. Nakajima, Y. Suzuki, and S. Yoshikawa, J. Photochem. Photobiol. A Chem., 184, 163 (2006).

8. K. Rajeshwar, M. K. Hossain, R. T. Macaluso, C. Janáky, A. Varga, and P. J. Kulesza, J. Electrochem. Soc., 165, H3192 (2018).

9. Z. Wu, Z. Zhao, G. Cheung, R. M. Doughty, A. R. Ballestas-Barrientos, B. Hirmez, R. Han, T. Maschmeyer, and F. E. Osterloh, J. Electrochem. Soc., 166, H3014 (2019).

10. K. Sivula and R. van de Krol, Nat. Rev. Mater, 15010 (2016).

11. A. Thomas, C. Janáky, G. F. Samu, M. N. Huda, P. Sarker, J. P. Liu, V. van Nguyen, E. H. Wang, K. A. Schug, and K. Rajeshwar, ChemSusChem, 8, 1652 (2015).

12. N. Myung, S. Ham, S. Choi, Y. Chae, W.-G. Kim, Y. J. Jeon, K.-J. Paeng, W. Chanmanee, N. R. de Tacconi, and K. Rajeshwar, J. Phys. Chem. C, 115, 7793 (2011).

13. M. Kodera, J. Wang, B. A. Nail, J. Liu, H. Urabe, T. Hisatomi, M. Katayama, T. Minegishi, F. E. Osterloh, and K. Domen, Chem. Phys. Lett., 683, 140 (2017).

14. N. K. Allam, B. S. Shaheen, and A. M. Hafez, ACS Appl. Mater. Interfaces, 6, 4609 (2014)

15. T. Varga, H. Haspel, A. Kormányos, C. Janáky, Á. Kukovecz, and Z. Kónya, Electrochim. Acta, 256, 299 (2017).

16. E. A. Bondarenko, E. A. Streltsov, M. V. Malashchonak, A. V. Mazanik, A. I. Kulak, and E. V. Skorb, Adv. Mater, 29, 1702387 (2017).

17. G. Wittstock, S. Rastgar, and S. Scarabino, Curr. Opin. Electrochem., 13, 25 (2019).
18. K. Honda, J. Photochem. Photobiol. A Chem., 166, 63 (2004).

19. K. Rajeshwar, J. Phys. Chem. Lett., 2, 1301 (2011).

20. K. Hashimoto, H. Irie, and A. Fujishima, 44, 8269 (2006).

21. B. Buchholcz, H. Haspel, Á. Kukovecz, and Z. Kónya, CrystEngComm, 16, 7486 (2014).

22. L. Shen, Z. Xing, J. Zou, Z. Li, X. Wu, Y. Zhang, Q. Zhu, S. Yang, and W. Zhou, Sci. Rep., 7, 1 (2017)

23. W. W. Lee, C.-S. Lu, C.-W. Chuang, Y.-J. Chen, J.-Y. Fu, C.-W. Siao, and C.-C. Chen, RSC Adv., 5, 23450 (2015)

24. S. Meng, Y. Bi, T. Yan, Y. Zhang, T. Wu, Y. Shao, D. Wei, and B. Du, J. Hazard. Mater. 358, 20 (2018)

25. H. K. Timmaji, W. Chanmanee, N. R. de Tacconi, and K. Rajeshwar, J. Adv. Oxid. Technol., 14, 93 (2011).

26. R. He, D. Xu, B. Cheng, J. Yu, and W. Ho, Nanoscale Horizons, 3, 464 (2018).

27. I. Herath, M. Vithanage, and J. Bundschuh, Env. Pollution, 223545 (2017).

28. S. A. Adonin, L. A. Frolova, M. N. Sokolov, G. V. Shilov, D. V. Korchagin, V. P. Fedin, S. M. Aldoshin, K. J. Stevenson, and P. A. Troshin, Adv. Energy Mater, 8, $1701140(2017)$

29. X. Y. Chen, H. S. Huh, and S. W. Lee, J. Solid State Chem., 181, 2127 (2008).

30. S. I. Ali and M. Johnsson, Dalt. Trans., 45, 12167 (2016).

31. V. Krämer, Acta Crystallogr. Sect. B Struct. Crystallogr. Cryst. Chem., 31, 234 (1975).

32. L. Yang, J. Huang, L. Cao, L. Shi, Q. Yu, X. Kong, and Y. Jie, Sci. Rep., 6, 27765 (2016).

33. S. Lian Wang, L. Li Wang, W. Hong Ma, D. M. Johnson, Y. Fen Fang, M. Ke Jia, and Y. Ping Huang, Chem. Eng. J., 259, 410 (2015).

34. M. Tamilselvan and A. J. Bhattacharyya, RSC Adv., 6, 105980 (2016).

35. M. Nowak, M. Jesionek, P. Szperlich, J. Szala, T. Rzychoń, and D. Stróz, Ultrason Sonochem., 16, 800 (2009).

36. A. Han, S. F. Chian, X. Y. Toy, J. Sun, S. Jaenicke, and G. K. Chuah, Res. Chem Intermed., 41, 9509 (2015).

37. V. Krämer, M. Schuhmacher, and R. Nitsche, Mater. Res. Bull., 8, 65 (1973).

38. I. D. Baikie, A. C. Grain, J. Sutherland, and J. Law, Appl. Surf. Sci., 323, 45 (2014).

39. M. Y. Valakh, Y. Veshka, G. S. Svechnikov, and Y. P. Kutsenko, Phys. Stat. Sol. B 99, 145 (1980).

40. A. Geng, L. Cao, C. Wan, and Y. Ma, Phys. Status Solidi C., 8, 1708 (2011).

41. C. A. Cody, L. Dlcarlo, and R. K. Darlington, Inorg. Chem., 18, 1572 (1979).

42. Z. Hugonin, M. Johnsson, and S. Lidin, Solid State Sci., 11, 24 (2009).

43. I. R. Jahn, W. Altenburger, W. Prandl, and V. Krämer, Acta Crystallogr. Sect. A Found. Crystallogr., 44, 1028 (1988).

44. S. E. Golunski, T. G. Nevell, and M. I. Pope, Thermochim. Acta, 51, 153 (1981).

45. M. Biver and W. Shotyk, Geochim. Cosmochim. Acta, 109, 268 (2013).

46. A. J. Göttle and M. T. M. Koper, Chem. Sci., 8, 458 (2017).

47. M. N. Jackson and Y. Surendranath, J. Am. Chem. Soc., 138, 3228 (2016).

48. I. Siewert, Chem. - A Eur. J., 21, 15078 (2015).

49. B. Samanta, D. Dutta, and S. Ghosh, Phys. B Phys. Condens. Matter, 515, 82 (2017).

50. J. Tauc, Mater. Res. Bull., 3, 37 (1968)

51. X. Liu, Y. Su, Q. Zhao, C. Du, and Z. Liu, Sci. Rep., 6, 28689 (2016).

52. Y. Bai, L. Ye, T. Chen, P. Wang, L. Wang, X. Shi, and P. K. Wong, Appl. Catal. B Environ., 203, 633 (2017). 